\title{
AN EMPIRICAL TEST OF CUSTOMER RETENTION-PERCEIVED QUALITY LINK: STRATEGIC MANAGEMENT IMPLICATIONS
}

\author{
Dr. Godwin Onyeaso \\ Dr. Chris Adalikwu \\ Concordia College-University System \\ Selma, AL
}

\begin{abstract}
This paper employed times series econometric methods to test the theoretically-grounded link between customer retention and customer perceived quality. The results suggest that customer retention and quality have a stable positive link binding them together, which allows them to move together in the same direction over time. Importantly, empirical evidence of long term Granger-type causality running from quality to retention, was found in support of this positive link. Finally, customers 'perception of quality yesterday has a positive impact on their level of retention today. It suggests that customers' memories of quality linger on beyond the current period to positively impact customer retention levels in the future. In this sense, quality is an intangible strategic asset in which service managers should invest their capital.
\end{abstract}

In her strategic service management paper, Zeithaml, $(2000$, p. 76$)$ states that: "Only a few research studies have been conducted that explicitly link service quality with customer retention (for exceptions, see Rust \& Zahorik 1993)." Consequently, our literature review revealed that, even among the few studies that linked service quality with customer retention, including those cited by Zethaml (2000), none used time series data and methods as proposed in the current paper. Second, related to the above, none of the studies used time series market-level aggregate data to investigate the hypothesized relationship linking consumer perceived service quality and customer retention. By market-level aggregate data, we mean data on all consumers of a particular service (e.g, consumers of Pizza Hut's pizza). Stated another way, past research relied exclusively on individual-level (consumer-level) data to investigate the quality-retention link. This prompts the question: Why should the differences between market-level and individual-level data sets have empirical significance in the quality-retention link?

One important implication of the difference between the two data sets can be stated as follows: The veracity of the results of past research may be dependent on the individual-level data they used to investigate the nature of the functional form linking consumer perceived quality and consumer retention. The empirical question then arises: Absent the use of individual-level data, would the conclusions of 
past research still hold? Stated another way, if market-level aggregate time series data are used to explore the functional relationship linking consumers'perception of service quality and consumer retention, would the result be the same as the results obtained by researchers using individual-level data sets? This question is difficult to answer because the use of market-level aggregate data in this area of research is extremely scanty (Johnson, Anderson \& Fornell, 1995).

Another important empirical question is: Does the level of customers' perceived service quality today positively impact the level of customer retention in the future? Intangible strategic assets theory predicts that the accumulation of intangible strategic assets such as perceived quality should be path-dependent (Dierickx \& Cool, 1989). By path-dependency we mean that the accumulation process of intangible strategic assets cannot be rushed without incurring an exponential increase in the cost of accumulation. This phenomenon has been dubbed time compression diseconomies (Dierickx \& Cool, 1989). In the same vein, the dissipation of intangible strategic assets such as perceived quality should be path-dependent under what is called asset erosion (Dierickx \& Cool, 1989). Asset erosion of intangible strategic assets theory is equivalent to depreciation in physical assets (Dierickx \& Cool, 1989). Because erosion of perceived quality is path-dependent, we expect that the impact of today's quality on future levels of customer retention will be positive and significant. Previous research on quality-retention could not investigate this dynamic impact because individual-level cross-sectional data have no information about the dynamic impact of quality on retention.

What are the contributions of the present paper? The main contribution of this paper is fourfold. First, if market-level aggregate data, produce results that are consistent with those of past research that used individual-level data, then a contribution will have been made because we now know that the same results can be obtained by using both types of data sets. That is, we now have collaborative empirical evidence using market-level time series data. On the other hand, if different results are obtained than those of individual-level data sets used by past research, a contribution will have been made because we now have empirical evidence that market-level data yielded contrary results to individual-level data. Either way, a contribution will have been made in the extant literature in this important area. Third, even though a test of the quality-retention link is not new, the application of time series data and method to confirm this theoretically grounded link is new. Finally, the intangible strategic assets theory (Dierickx \& Cool, 1989; Amit \& Shoemaker, 1993) predicts that the dynamic impact of today's quality on the future levels of customer retention should be positive and significant. We also investigate this hypothesis.

This paper begins by presenting a condensed literature review leading to hypotheses. This is followed by a methodology section discussing data sources and construct measurement issues. Then, the data analyses section discusses statistical methods used but relegated to the Appendix. The paper concludes with a discussion of empirical results and managerial implications and conclusions. 


\section{Literature and Hypotheses}

Consistent with a stream of research in service management calling for theoretically driven service management research (e.g., Dholakia, Firat \& Bagozzi, 1980; Ozanne \& Murray, 1991, 1995; Gronroos, 1994; Brownlie, Saren, Wensley \& Whittington, 1999; Zeithaml, 2000; Gummesson, 2001; Burton, 2001), some service management strategists have argued that theory development in service management should begin with empirical tests of key service marketing constructs (Gronroos, 1994; Zeithaml, 2000; Gummesson, 2001) rather than depend on theory from other disciplines (Burton, 2005). In concurring with this view, Zeithaml, (2000, p. 76) concluded that "Many issues about customer retention still need to be examined." Specifically, she urged service marketing researchers to empirically investigate the link between service quality and customer retention (Zeithaml, 2000). As an empirical support to this view, earlier work suggested that service quality is related to customer retention through a reduction in customer defection rate (Reichheld \& Sasser, 1990). Thus, there is the impetus for further research in quality-retention link.

From a marketing perspective, customer relationship equity postulates that a firm's value is a product of the totality of the discounted future profit streams from its retained customers (Rust, Zeithaml \& Lemon, 2000). According to this perspective, a high customer relationship equity arising from customers' perception of quality in a firm's offerings reduces customer defection rates and hence increases customer retention. In the same vein, Rust and Zahorik (1993) used a mathematical model to illustrate that customer satisfaction is a major driver of retention rate, and the latter is positively related to market share. Stated differently, without customer satisfaction, the positive link between retention and market share will vanish. In their study of the effects of complaints-handling programs on customer retention, Fornell and Wernerfelt $(1987,1988)$ found a positive link between customer satisfaction and profit. It is noteworthy that these preceding studies focused on the role of customer satisfaction on retention and hence profit, with the implicit assumption that quality and satisfaction are interchangeable (a controversial topic). In one of the most comprehensive studies of the role of service quality, Zeithaml, Berry, and Parasuraman (1996) conclude that service quality influences different consumer behavioral intentions: willingness to pay more, to recommend a business, and increased patronage. From the perspective of the economics of retention (Reichheld, 1996a,b), marginal increases in retention rate can have phenomenal positive effects on corporate profits because the cost of retaining an existing customer is less than the cost of acquiring a new one. Notably, existing customers patronize a firm more than new customers, and there are other exchange efficiencies associated with existing customers (Fornell \& Wernerfelt, 1987, 1988; Reichheld \& Sasser, 1990).

To the extent that behavioral intentions of customer retention materialize in actual customer retention, a growing body of research suggests that the statistical evidence of quality-retention link is positively significant. It has been suggested 
that service quality has a direct effect on organizations' profits, since it is positively related with customer retention and with customer loyalty.

Because previous works also suggest that service quality is a major factor for building superior competitive advantage when marketing assets are deployed for superior service quality (Ennew, Reed \& Binks, 1993; Zeithaml et al., 1996) across industries (Gronroos, 2000). Consistent with this notion, because customer retention provides repeat purchase patronage as the bedrock of superior competitive advantage, customer perceived quality and retention are expected to be empirically linked, as supported by customer relationship research (Reichheld, $1996 a, b)$. Finally, Venetis and Ghauri (2004) argue that service quality is linked to organizational profitability through two routes, and each of these routes involves customer retention. Management can deploy a company's marketing assets to acquire superior service quality that differentiates the company from its competitors, and, in turn, leverage the company's competitive advantage through greater market share and profitability as the Profit Impact of Marketing Strategies (PIMS) studies indicate (Buzzell \& Gale, 1987). In the second route, "service quality is viewed as an important means for customer retention" (Zeithaml et al., 1996). All in all, the preceding discussion suggests the following hypotheses.

\section{Hypothesis 1: Customers perceived service quality and customer reten- tion will be positively linked.}

Hypothesis 2: Given the positive link between quality and retention, both will move in tandem in the same direction.

We now turn to another important empirical question: Does the level of quality perceived by customers today have positive impact on the level of customer retention in the future? Stated another way: Does the level of quality perceived by customers yesterday have positive impact on the level of customer retention today? Research in this dynamic view of quality as it impacts customer retention is scanty, albeit important. To see its importance, the architects of the PIMS studies aimed to uncover the long run dynamic impact of quality on behavioral outcomes such as return on investment (ROI) via the positive impact of quality on customer retention. The panel form of the PIMS annual data was instrumental in these dynamic analyses (Buzzell \& Gale, 1987). In this framework, the PIMS study examined causes of long run performance differences among strategic business units (SBUs) across industries. The managerial motivation being that organizational performance and ultimate survival is predicated on the notion of long run profitability, and that is why managers craft corporate strategy (Barney, 1991; Porter, 1991).

In the PIMS studies, market share is used as a proxy for product or service quality, the idea being that if customers do not perceive quality in a firm's product or service - the firm's market share will vanish (Buzzell, 2004) because retention is the principal component of market share as shown in defensive marketing 
strategy studies (Fornell \& Wernerfelt, 1987, 1988; Rust \& Zahorik (1993, p. 212). In the same vein, customers are retained because they see quality and hence value in a firm's services. In another study, $26 \%$ of the variance in the duration of the relationship between a customer and a service provider is explained by satisfaction of customers (Bolton, 1998). Likewise, research suggests that customers are willing to pay higher prices for quality rather than compromise quality, and they are willing to do so in a long run exchange relationship that keeps them retained for the firm under the rubrics of customer relationship management (Sheth \& Parvatiyar, 1995; Duncan \& Moriarty, 1998; Cronin, Brandy \& Hult, 2000; Gronroos, 2000). In this latter framework, both quality and long run customer retention impact current changes in retention under the notion of exchange efficiency as the bedrock of customer relationship management (Gronroos, 1993, 2000; Kotler, 1994; Sheth \& Parvatiyar, 1995). Exchange efficiency, in turn, derives from long run customer retention economics because the longer the customer is retained the greater the expected cash flow trajectory to the company, and the lower the exchange cost the customer incurs (Sheth \& Parvatiyar, 1995). Because a retained customer has higher likelihood of being retained, past level of retention will positively impact current level of retention (Gronoors, 2000). Similarly, past levels of quality should positively impact current levels of retention according to key strands in Kotler (1994). This prompts the question: Does the level of quality perceived by customers yesterday have positive impact on the level of customer retention today?

\section{Hypothesis 3: Customers 'level of perceived quality today will positively impact their level of retention tomorrow.}

\section{Method}

\section{Data and the Unit of Analysis}

To test these hypotheses, a national chain fast food restaurant was used as the unit of analysis of this study because customer complaints arising from poor quality were rampant, suggesting that retention may be low in that industry (Tax, Brown \& Chandrasshekaran, 1998). The data were generously donated to us by University of Michigan School of Business under a binding anonymity contract. Fornell, Johnson, Anderson, and Bryant (1996) provide a detailed discussion of these data covering 1994 to 2003 . The data were quarterized and logged (40 observations). Finite sample bias correction was applied because of potential small sample problems, as discussed in the analysis section of this paper.

Even though Fornell et al. (1996) provide a detailed discussion of customer perceived quality and retention, we believe that it is necessary to present a brief discussion of the data and the measurement of these variables. Begun in 1994, the ACSI is "a uniform, national, cross-industry measure of satisfaction with the quality of goods and services available in the United States of America." "The ACSI measures each company once in a year [and] the measure is cumulative 
in the sense that it aims to capture all relevant customer experience (with the product or service) to date" (Fornell et al., 2006, p. 6). The ACSI uses a survey based on computer-assisted-telephone-interviewing (CATI) whereby customers are chosen randomly from national and regional probability samples of continental U.S. households. Random-digit-dialing (RDD) allows the ACSI to select households with listed and unlisted telephone numbers. The individual whose birthday is the most recent is picked as a respondent in each household. This way, ACSI obtains a representative distribution of respondents in terms of gender, age and other demographic variables.

For the ACSI, the word "respondent" and "customer" are used interchangeably so that a respondent is a buyer of specific products or services within a specific time period. In this framework, a respondent customer is defined as "an individual chosen randomly from a large universe of potential buyers..." For example, in the Industry: Restaurant/fast food pizza, carryout. The following question is used to identify a customer:

"Have you purchased food from a fast food restaurant or pizza restaurant, to eat in the restaurant, for carryout, or ordered for home delivery in the last three months?" (IF YES) "At which fast food restaurant have you most often purchased food to eat in the restaurant, for carryout, or ordered for home delivery in the last three months? (IF MORE THAN ONE, EMPHASIZE MOST OFTEN)."

\section{Measurement of Perceived Service Quality}

Perceived quality is the first determinant of cumulative customer satisfaction according to the ACSI. ACSI index states that perceived quality "is the served market's evaluation of recent consumption experience, and is expected to have a direct and positive effect on overall customer satisfaction" (Fornell et al., 1996, p. 9). Specifically, ACSI measures perceived quality based on "two primary components of consumption experience: (1) customization, that is, the degree to which the firm's offering is customized to meet heterogeneous customer needs, and (2) reliability; that is, the degree to which the firm's offering is reliable, standardized, and free from deficiencies" (Fornell et al., 1996, p. 9).

\section{Measurement of Customer Retention}

According to ACSI statisticians, the customer retention measure is an estimate "based on a non-linear transformation of the repurchase likelihood question." Basically, the repurchase likelihood question asks the customer: "how likely are you to purchase from the same supplier in the future?" In this framework, "below a certain point on the repurchase likelihood question we assume the customer will definitely not be retained, and then recode the rest of the responses above this point on a 0-.9 scale." (Morgeson, 2005). The measurement of customer retention construct used in this study was obtained using this method. 


\section{Reliability and Validity of Measures}

Notably, the reliability (signal-to-noise ratio) and validity (the degree to which measures represent the underlying latent constructs) have been reported to be satisfactory for all the constructs in the ACSI index, including the above constructs used in the present study (ACSI Methodology Report, 2001, pp. 17-18). We may add that, interestingly, none of the past and recent studies that employed the ACSI constructs attempted to discuss the ACSI methodology and measures as done in the present paper (Fornell et al., 2006; Mittal, Anderson, Sayrak \& Tadikamalla, 2005; Auh \& Johnson, 2005).

\section{Analyses}

To enhance readability of this section, technical details are relegated to the Appendix. Cointegration analysis follows sequential steps. In the first step, an overview of cointegration methods is presented in Appendix 1A. As discussed in that Appendix, cointegration begins with an investigation of the order of integration of the variables in the study. The Augmented Dickey-Fuller (ADF) test was used to ascertain of integration of the variables, and the results of the ADF tests are shown in Table 1 in Appendix 1B (Dickey \& Fuller, 1981). Then, conditional on the results in Table 1, the following three cointegration methods were used to analyze the data: the fully-modified ordinary least squares (FMOLS) of Phillips-Hansen (1990), the one-shot cointegration estimation approach proposed by Banerjee, Dolado, Hendry and Smith (1986, hereafter, BDHS), also called Hendry's dynamic regression method, and Stock and Watson (1993) dynamic ordinary least squares (DOLS). The major superiority of the DOLS is that it is robust in small samples and simultaneity bias compared to other methods because it includes leads and lags of changes in the regressors to neutralize the effects of these biases. All in all, all three methods yielded the same substantive results which suggest that these results are not the artifacts of the methods used. However, to save space and keep technical details to a minimum, only the FMOLS results are reported in Table 2 on the next page (technical details of the FM-OLS are presented in Appendix 1C). Readers interested in the results not reported here can obtain them from the authors. 
Table 2

Phillips-Hansen FM-OLS Long Run and Short Run Results

\begin{tabular}{cc}
\hline $\begin{array}{c}\text { Long Run Results: Customer Retention is Dependent Variable } \\
\text { Regressors }\end{array}$ & $\begin{array}{c}\text { Parameter Estimate } \\
\text { Constant }\end{array}$ \\
LPQ & $-2.83(.22)$ \\
& $1.62(.004)^{*}$ \\
\hline Short Run Results: Change in Customer Retention is Dependent Variable & Parameter Estimate \\
Regressors & $.13(.029)^{*}$ \\
\hline Constant & $-1.28(.006)^{*}$ \\
PHECM $(-1)$ & $1.76(.000)^{*}$ \\
$\Delta L C R(-1)$ & $.99(.004)^{*}$ \\
$\Delta L P Q$ & $2.38(.001)^{*}$ \\
$\Delta L P Q(-1)$ & $-.97(.008)^{*}$ \\
$\Delta L P Q(-4)$ & $-.73(.029)^{*}$ \\
$\Delta L P Q(-7)$ & \\
\hline & \\
\hline R-Squared Adjusted $=0.67$ & Diagnostic Tests \\
Serial Correlation: & \\
F-Version (4, 12$)=38(.81)$ & \\
Normality $\mathrm{c}^{2}{ }_{(2)}=2.1(.33)$ & \\
Heteroscedasicity, $F(1,27)=1.4(.247)$ & \\
PHECM (-1) t-ratio $=-3.16(.006)$. & \\
\hline
\end{tabular}

${ }^{*} p<0.05$. P-values are in parentheses. The negative coefficients on lags $4 \& 7$ of $\triangle L P Q$ can be ascribed to instability of reduced form equations (ECM) as the lag increases.

\section{Summary of Hypotheses}

\section{Hypothesis 1}

Hypothesis 1 proposes that customers' levels of perceived service quality and customer retention will be positively linked. The results of Phillips-Hansen FMOLS approach reported in Table 2 suggest that quality and retention are positively related or linked $(p<.05)$. Again, the same results were obtained by the BDHS and DOLS methods, but to save space, they were not reported here.

\section{Hypothesis 2}

Hypothesis 2 proposes that, given the positive link between quality and retention, both will move in tandem in the same direction. As can be seen in Table 2, the positive association between quality and retention allows the inference that both will move in the same direction (Engle \& Granger, 1987). Again, the same results were obtained using BDHS and DOLS methods, but to save space, they were not reported here. 


\section{Hypothesis 3}

Hypothesis 3 proposes that customers' level of perceived quality today will positively impact their level of retention tomorrow. As can be seen, empirical evidence in Tables 2 and 3 suggests that the effect of quality yesterday has positive impact on today's level of retention. Again, the same results were obtained using BDHS and DOLS methods, though not reported to save space.

\section{Assessment of Findings}

In this section, we assess the findings of this study and then discuss the managerial significance of the findings. This study was motivated by a neglected research gap and subsequent calls to fill it. Specifically, Zeithaml (2000. p. 76) remarked that "only a few studies have been conducted that explicitly link service quality with customer retention (for exception, see Rust \& Zahorik, 1993). As a response to this call, the present study empirically tested whether service quality is linked to customer retention. Unlike past research on quality-retention link, our study used a market-level time series longitudinal data set to investigate the dynamic relationships linking quality and retention, so that strategic insights useful to service industry managers would be uncovered.

Overall, the empirical evidence suggests that service quality is linked positively to customer retention as hypothesized. In addition, we found that there appears to be a permanent (long-term) Granger-type causality between customer retention and quality. By Granger-type causality we mean temporal causality. Finally, empirical evidence of cointegrating relationship between these variables means that these variable move in tandem (Engle \& Granger, 1987). We are not aware of any other study on quality-retention link that found Granger-type causality among them. Likewise, we are not aware of previous study that found dynamic impact of quality on retention. We now turn to the practical strategic management significance of this study's results to managers in the service industry with particular emphasis to fast food restaurants.

\section{Managerial Strategic Management Implications}

There is no shortage of verifiable evidence that the fortunes of service organizations are positively correlated with the extent their managers deploy their marketing assets to provide superior quality to their customers in the present competitive environment (Parasuraman, Zeithaml \& Berry, 1988; Zeithaml, 1988, 2000; Reichheld \& Sasser, 1990; Gronroos, 2000; Zeithaml, Berry \& Parasuraman, 1996; Fomell \& Wernerfelt, 1987). Because service quality can boost organizational performance, it is an intangible strategic asset with key attributes such as path-dependent accumulation trajectory (Dierick \& Cool, 1989; Amit \& Shoemaker, 1993; Michalisin $\&$ Kline, 1997). Notably, this inherent trajectory is reflective of an autoregressive behavior in the accumulation process as well as in the deployment and dissipation (asset erosion) process of quality as a strategic asset (Dierickx \& Hanssens, 2000). 
By autoregressive we mean that the adjacent values of quality observed in discrete time are serially self-correlated over time. This phenomenon has two immediate implications for theory development with specific focus on quality and customer retention in the present paper. First, lagged effect of quality is a significant predictor of current quality as well as current customer retention levels as related work in terms of this autoregressive methodology attests (Jacobson \& Aaker, 1987). In other words, customers have memory because quality perceived by customers in past periods can help explain the level of quality they perceive in the current period as well as the level of retention in the current period. Sadly, there is a shortage of verifiable evidence that service managers are aware of this strategic significance of quality. Specifically, managers should know that: (1) quality is a strategic asset, (2) accumulation cannot be rushed, (3) once accumulated, quality has a long payback period far beyond the time and the cost of its accumulation, and (4) ex-post quality accumulation, quality as a strategic asset should be protected by the two so-called ex-post limits to competition - inimitability and non-substitutability. Space constraint does not allow full discussion of the latter two strategic management terms (Barney, 1991).

\section{Limitations and Directions for Future Research}

The functional form of the link between customer retention and quality was the primary purpose of this paper. The drivers of retention and quality were beyond the purpose of this paper, the investigation of the drivers is left for future research. Because restaurants are ranked number one in the frequency of customer complaints due to low customer perceived quality (Tax et al., 1998), the study used a fast food restaurant as its unit of analysis. Future research is encouraged to extend or replicate this study using other service industries in the USA or any other country.

\section{Conclusions}

Our literature review suggests that the customer retention-quality link is important but ill-understood and under-researched (Zeithaml, 2000). This research void has implications in terms of theory development as well as practical managerial significance. Consequently, this study employed recent advances in time series econometrics to investigate the functional form of the quality-retention link in the framework of three hypotheses tested, using market-level data on fast food patronage.

Overall, the empirical evidence suggests that service quality is linked positively to customer retention as hypothesized. In addition, we found that there appears to be a permanent (long-term) Granger-type causality between customer retention and quality. By Granger-type causality we mean temporal causality. Finally, empirical evidence of cointegrating relationship between these variables means that these variable move in tandem (Engle \& Granger, 1987). We are not aware 
of any other study on quality-retention link that found Granger-type causality among them. Likewise, we are not aware of previous study that found dynamic impact of quality on retention.

Summing up, the findings of the paper have strategic management significance about quality and customer retention in terms of complementary, intangible strategic assets (Amit \& Schoemaker, 1993). It draws from the intangible assets accumulation theory proposed by Dierickx and $\mathrm{Cool}(1989)$ in their response to Barney $(1986,1989)$.

\section{References}

Amit, R., \& Schoemaker, P. J. (1993). Strategic assets and organizational rent. Strategic Management Journal, 14, 33-46.

Arize, A. C., Malindretos, J., \& Grivoyannis, E. C. (2003). Inflation rate volatility and money demand: Evidence from less developed countries. International Review of Economics \& Finance, (in Press).

Arize, A. C., Malindretos, J., \& Christoffersen, S. (2003). Monetary dynamics, exchange rates and parameter instability: An empirical investigation. Journal of Economic Studies, 30(5), 493-513.

Auh, S., \& Johnson, M. D. (2005). Compatibility effects in evaluations of satisfaction and loyalty. Journal of Economic Psychology, 26, 35-57.

Banerjee, A., Dolado J., Hendry D., \& Smith G. (1986). Exploring equilibrium relationships in econometrics through static models: Some Monte Carlo evidence. Oxford Bulletin of Economics and Statistics, 48(3), 253- 277.

Barney, J. (1991). Firm resources and sustained competitive advantage. Journal of Management, 17(1), 99-120.

Barney, J. (1989). Asset stock and sustained competitive advantage: A comment. Management Science, 35, 1511-1513.

Barney, J. (1986). Strategic factor markets: Expectations, luck and business strategy. Management Science, 32, 1231-1241.

Bolton, R. N. (1998). A dynamic model of the duration of the customer's relationship with a continuous service provider: The role of satisfaction. Marketing Science, $17(1), 45-65$.

Brownlie, D., Saren, M., Wensley, R., \& Whittington, R. (1999). Marketing disequilibrium: On redress and restoration. In D. Brownlie, M. Saren, R. Wensley \& R. Whittington (Eds.), Rethinking Marketing. Sage Publication. 
Burton, D. (2005). Marketing theory matters. British Journal of Management, 16, 5-18.

Burton, D. (2001). Critical Marketing theory: The blueprint? European Journal of Marketing, 35(5/6), 722-743.

Buzzell, R., \& Gale, B. (2004). The PIMS program of strategy research: A retrospective appraisal. Journal of Business Strategy, 54, 478-483.

Buzzell, R., \& Gale, B. (1987). The PIMS principles: Linking strategy to performance. New York: Free Press.

Cronin, J. J., Brandy, M., \& Hult, G. T. (2000). Assessing the effects of quality, value, and customer satisfaction on consumer behavioral intentions in service environments. Journal of Retailing, 76(2), 193-218.

Dekimpe, M. G. \& Hanssens, D. M. (2000). Time series models in marketing: Past, present and future. International Journal of Research in Marketing, 17(2-3), 183-193.

Dholakia, N., Firat, A. F, \& Bagozzi, R. P. (1980). The de-Americanization of marketing thought: In search of a universal basis. In C.W. Lamb and P. M. Dunne (Eds.), Theoretical Developments in Marketing, AMA Conference Proceedings, 10-13 February, Phoenix, AZ.

Dickey, D. A., \& Fuller, W. A. (1981), Likelihood ratio statistics for the autoregressive time series with a unit root. Econometrica, 49, 1057-1072.

Dierickx, I., \& Cool, K. (1989). Asset stock accumulation and sustainability of competitive advantage. Management Science, 35(12), 1504-1513.

Duncan, T., \& Moriarty, S. E. (1998). A communication-based marketing model for managing relationships. Journal of Marketing, 62(April), 1-13.

Enders, Walter. (2004). Applied econometric time series. New York: Wiley.

Ennew, C. T., Reed, G. V., \& Binks, M. R. (1993). Importance-performance analysis and the measurement of service quality, European Journal of Marketing, 27(2), 59-70.

Engle, R., \& Granger, C. W. J. (1987). Cointegration and error correction: Representation, estimation and testing. Econometrica, 55, 251-76

Formell, C., \& Wernerfelt, B. (1987). Defensive marketing strategy by customer complaint management: A theoretical analysis. Journal of Marketing Research, 24(November), 337-346.

Fornell, C., \& Wernerfelt, B. (1988). A model for customer complaint management. Marketing Science, 7, 271-286. 
Fornell, C., Johnson, M. D., Anderson, E. W., Cha, J., \& Bryant, B. E. (1996). The American customer satisfaction index: Nature, purpose and findings. Journal of Marketing, 60, 7-18.

Fornell, C., Mithas, S., Morgeson III, F. V., \& Krishnan, M. S. (2006), Customer satisfaction and stock prices: High returns, low risk. Journal of Marketing, 70, 3-14.

Granger, C. W. J., (1988). Some recent developments in the concept of causality, Journal of Econometrics, 39, 199-211.

Granger, C. W. J., \& Newbold, P. (1974). Economic forecasting: The atheist's viewpoint. In G.A. Renton (Ed.), Modeling the Economy. London: Heinemann.

Gummesson, E. (2001). Are current approaches in marketing leading us astray? Marketing Theory, $1(1), 27-48$.

Gronroos, C. (1994). From marketing mix to relationship marketing towards a paradigm shift in marketing. Management Decision, 32(20), 1-19.

Gronroos, C. (1993). From scientific management to service management: A management perspective for the age of service competition. International Journal of Service Industry Management, 3(5), 5-20.

Gronroos, C. (2000). Service management and marketing: A customer relationship marketing approach. Second Edition. Chichester, UK: Wiley.

Gonzalo, J. (1994). Five alternative methods of estimating long run equilibrium relationships. Journal of Econometrics, 60, 203-233.

Haug, A. (1996). Tests for cointegration: A Monte Carlo comparison. Journal of Econometrics, $71,89-115$.

Hamilton, J. D. (1994). Time series analysis. Princeton, NJ: Princeton University Press.

Harris, R. (1995). Using cointegration analysis in econometric modeling. New York: Prentice-Hall.

Hendry, D. F. (1995). Dynamic econometrics, New York: Oxford University Press.

Jacobson, R., \& Aaker, D. A. (1987). The strategic role of quality, Journal of Marketing, 51(October), 31-44.

Johansen, S., \& Juselius, K. (1990). Maximum likelihood estimation and inference on cointegration with application to the demand for money. Oxford Bulletin of Economics and Statistics, 52, 169-210. 
Johnson, M. D., Anderson, E. W., \& Formell, C. (1995). Rational and adaptive performance expectations in a customer satisfaction framework. Journal of Consumer Research, $21,128-140$.

Kotler, P. (1994). Marketing management: Analysis, planning, implementation and control. Englewood Cliffs, NJ: Prentice-Hall

Michalisin, M. D., Smith, R. D., \& Kline, D. M. (1997). In search of strategic assets. The International Journal of Organizational Analysis, 5(4), 360-387.

Mittal, V., Anderson, E. W., Sayrak, A., \& Tadikamalla, P. (2005). Dual emphasis and the long term financial impact of customer satisfaction. Marketing Science, 24(4), 544-555.

Morgeson, F. (2005). Personal Communication.

Ozanne, J. L., \& Murray, J. B. (1991). The critical imagination: Emancipatory interest in consumer research. Journal of Consumer Research, 18(September), 129-144.

Ozanne, J. L., \& Murray, J. B. (1995). Uniting critical theory and public policy to create the reflexively defiant consumer. American Behavioral Scientist, 38(4), 516-525.

Parasuraman, A., Zeithaml, V., \& Berry, L., (1988). SERVQUAL: A multiple-item scaie for measuring consumer perceptions of service quality. Journal of Retailing, 64(2), $12-40$.

Phillips, P. C. B., \& Hansen, B. E. (1990). Statistical inference in instrumental variables regression with I (1) process, Review of Economic Studies, 57, 99-125.

Porter, M. E. (1991). Towards a dynamic theory of strategy. Strategic Management Journal, 12, 95-118.

Reichheld, F. F., \& Sasser, W. E. (1990). Zero defection: Quality comes to services. Harvard Business Review, 68(5), 105-111.

Reichheld, F. F. (1996a). The loyalty effect. Cambridge, MA: Harvard Business School Press.

Reichheld, F. F. (1996b). Learning from customer defections. Harvard Business Review, March-April, 56-69.

Rust, R. T., Zeithaml, V. A., \& Lemon, K. N. (2000). Driving customer equity: How customer lifetime value is reshaping corporate strategy. New York: Free Press.

Rust, R. T., \& Zahorik, A. J. (1993). Customer satisfaction, customer retention, and market share. Journal of Retailing, 69(2), 193-215. 
Sheth, J., \& Parvatiyar, A. (1995). Relationships in consumer markets: Antecedents and consequences. Journal of the Academy of Marketing Science, 23(4), 255-271.

Stock, J. H., \& Watson, M. (1993). A simple estimator of cointegrating vectors in higher order integrated systems. Econometrica, 61, 783-820

Tax, S. S., Brown, S. W., \& Chandrasshekaran, M. (1998). Customer evaluation of service complaint experience: Implications for relationship marketing. Journal of Marketing, 62, 60-76.

Thomas, R. L. (1996). Modern econometrics. New York: Addison-Wesley.

Venetis, K. A., \& Ghauri, P. N. (2004). Service quality and customer retention: Building long-term relationships. European Journal of Marketing, 38(11-12), 1577-98.

Zeithaml, V. A. (2000). Service quality, profitability, and the economic worth of customers: What we know and what we need to learn. Journal of the Academy of marketing Science, $28(1), 67-85$.

Zeithaml, V. A. (1988). Consumer perceptions of price, quality, and value: A means-end model and synthesis of evidence. Journal of Marketing, 52(July), 2-22.

Zeithaml, V. A., Berry L. L., \& Parasuramann, A. (1996). The behavioral consequences of service quality. Journal of Marketing, 60(April), 31- 46.

\section{Appendix 1A}

\section{Overview of Cointegration Approach}

Cointegration methods were used to test the hypotheses because it has the statistical capability to test these hypotheses. Cointegration analysis begins by recognizing that many time series variables, such as customer perceived quality and customer retention, are time dependent. This implies that they have time trend which renders them non-stationary with their means, variances and co-variances being time-dependent. As a consequence, direct application of OLS and GLS without differencing the variables results in spurious regression because these statistical methods are based on the assumption of stationary data (Granger \& Newbold, 1974). Therefore, the variables have to be differenced to make them stationary.

For example, in this paper, let $R_{t}$ denote observation on customer retention in time $t$ for a particular fast food restaurant, then $\Delta R_{t}=R_{t}-R_{t}$ is the first difference of $R$, which may be stationary, where stationary is labeled I $(0)$. If it is stationary with this first differencing, then retention is said to be integrated of order one, denoted as I(1). But, if is not stationary on first differencing, more differencing will be needed to make it stationary so that, if it takes differencing the retention $\mathrm{k}$ times to make it stationary, then retention is said to be integrated of order $\mathrm{k}$, 
denoted as $I(k))$. In applied works, however, techniques are available to uncover the order of integration of each of the variables in a particular model. What is cointegration?

From the above discussion, since we denoted retention at time t as $R_{t}$, let $Q_{t}$ denote perceived quality at time $t$. Assuming that retention is a function of quality, and that each of these variables is I(1) individually, then a long run equilibrium relationship between them exists which may be expressed as follows

$$
R_{t}=\alpha+\beta Q_{t}+\mu_{\mathrm{t}}
$$

The long run relationship in model (1) has a corresponding short run counterpart which may be expressed as follows

$$
R_{t}-\alpha-\beta Q_{t} \equiv \mu_{t}
$$

Model (2) represents a linear combination of retention and quality that is stationary, (i.e., I(0)) because it should not exhibit any tendency to increase with time. Thus, even though each of these two variables is $I(1)$, a linear combination of them is stationary. Therefore, retention and quality are cointegrated. In a nutshell, cointegration is a search for a linear combination that is $I(0)$ among a set of variables that are individually I(1). However, space constraint does not permit a detailed discussion of cointgration in this paper, good discussion are elsewhere (Hendry, 1995; Enders, 2004; Engle \& Granger, 1987; Hamilton, 1994).

\section{Appendix 1B}

\section{Order of Integration}

As discussed above, customer retention and perceived quality must be empirically shown to have the same order of integration before applying cointegration methods. To this end, the Augmented Dickey-Fuller (ADF) (Dickey \& Fuller, 1981) test was used to ascertain the order of integration of these variables. The $\mathrm{ADF}$ is based on the t-statistic on $\mathrm{f}$ in the following regression model

$$
\Delta Y_{t}=\alpha_{0}+\alpha_{1} t+\mathrm{f} Y_{t-1}+\stackrel{S}{i=1}_{p}^{n} \Delta Y_{t-1}+e_{t}
$$

where $\Delta$ is the first difference operator, $Y$ is the series (retention and quality), $e_{t}$ is a white noise stationary error term, and $\mathrm{n}$ is made large enough to ensure that $e_{t}$ is white noise. Here, the null is that $Y_{t}$ is a non-stationary series or a stochastic trend process, and the null is rejected when negative fis mathematically greater than the relevant critical values at the conventional levels, or negative $f$ is greater than corresponding critical values in absolute terms. The results are shown in Table 1. 
Table1

ADF Unit Root Tests

\begin{tabular}{|c|c|c|c|c|}
\hline \multicolumn{5}{|c|}{ ADF } \\
\hline \multirow[t]{2}{*}{ Series: } & \multicolumn{2}{|c|}{ LeveliFirst Diff } & & \\
\hline & \multicolumn{2}{|c|}{ With intercept \& Trend } & $95 \%$ Critical Value & Conclusion \\
\hline $\log C R$ & $\begin{array}{l}\text { Level } \\
\text { First Diff. }\end{array}$ & $\begin{array}{l}-2.78(1) \\
-4.94(3)\end{array}$ & $\begin{array}{l}-3.54 \\
-3.54\end{array}$ & $\begin{array}{l}I(1) \\
I(0)\end{array}$ \\
\hline $\log P Q$ & $\begin{array}{l}\text { Level } \\
\text { First Diff. }\end{array}$ & $\begin{array}{l}-2.03(1) \\
-4.25(1)\end{array}$ & $\begin{array}{l}-3.54 \\
-3.54\end{array}$ & $\begin{array}{l}I(1) \\
I(0)\end{array}$ \\
\hline
\end{tabular}

Notes: () denotes aggumentation lags selected using Akaike Information Criterion (AIC) andlor Schwarz Bayesian Criterion ( $\mathrm{SBC}$ ), $\mathrm{CR}$ is customer retention and $\mathrm{PQ}$ is perceived quality, these notations are used for all the Tables.

\section{Table 3}

Phillips-Hansen FM-OLS Short Run (ECM) Results: White's Heteroscedasticity Adjusted Standard Errors.

\begin{tabular}{|c|c|}
\hline \multicolumn{2}{|c|}{ Change in Customer Retention is Dependent Variable } \\
\hline Regressors & Parameter Estimate \\
\hline Consiant & $.13(.08)$ \\
\hline PHECM $(-1)$ & $-1.28(.05)^{\star}$ \\
\hline$\triangle L C R(-1)$ & $1.76(.001)^{*}$ \\
\hline$\triangle L P Q$ & $.99(.006)^{*}$ \\
\hline$\triangle L P Q(-1)$ & $2.38(.006)^{\star}$ \\
\hline$\triangle L P Q(-4)$ & $-.97(.010)^{*}$ \\
\hline$\triangle L P Q(-7)$ & $-.73(.066)$ \\
\hline \multicolumn{2}{|c|}{ PHECM $(-1)$ t-ratio $=-3.16(.006)$} \\
\hline
\end{tabular}

$* p<0.05$. P-values are in parentheses. The negative coefficients on lags $4 \& 7$ of $\triangle L P Q$ can be ascribed to instability of reduced form equations (ECM).

\section{Appendix 1C}

\section{Cointegration Tests}

Based on the evidence in Table 1, customer retention and customer perceived quality are individually first difference stationary, that is I(1). This is so because the null of no unit root could not be rejected $(p<.05)$ for each of these variables on their levels, and the null no unit root was rejected $(\mathrm{p}<.05)$ on their first differences. Conditional on these results, cointegration methods can then be applied. Because cointegration methods differ in terms of their relative capabilities in accomplishing different tasks (Gonzalo, 1994; Haug, 1996), two cointegration methods were employed based on their relative capabilities. While we present a 
brief discussion of each method, the well known Johansen and Juselius (1990) method was not used in this study because its application is more appropriate in the case of more than two variables (Harris, 1995).

\section{Hendry's Dynamic Regression Method}

This one-shot cointegration estimation approach estimates the short run and the long run parameters in one step rather than in two steps. The detailed discussion is provided by Banerjee et al. (1986, hereafter, BDHS). Our rationale for employing it is based on the following relative capabilities it has over other methods. First, according to BDHS, the small sample bias in the Engle and Granger two-step cointegration method can be at least minimized if the short run and the long run parameters are estimated in one step. Second, BDHS used a simulation study to demonstrate the relative small sample superiority of their method over competing methods. Finally, the BDHS method permits a test of cointegration by estimating their model and then testing whether the residual is stationary, according to Thomas (1996). If it is stationary, there is cointegration among the variables.

The next question is: If cointegration exists among the variables, how many vectors are there? The reduced rank theory (Johansen \& Juselius, 1990), states that the number of cointegration vectors (rank) in a model is one less than the number of variables in that model. Consistent with this theory, in a bivariate system such as the present paper, the number of cointegration vectors must be one.

\section{Phillips-Hansen FM-OLS Method}

The fully-modified ordinary least squares (FM-OLS) of Phillips-Hansen (1990) was also used in this paper to test the hypotheses. The FM-OLS is one of the robust single equation cointegration methods suggested by some authors on the basis of their capabilities relative to other methods (Haug, 1996; Stock \& Watson, 1993). Importantly, according to Haug (1996), the FM-OLS is asymptotically equivalent to the full information system-based estimator of Johansen and Juselius (1990). Consequently, in the framework of the FM-OLS, a truncation lag of 5 with Bartlett weights was applied to obtain the long run cointegration relationship between customer retention and perceived quality reported in Table 2 .

Evidence of cointegration automatically means that customer retention and quality have positive association which binds them together (Granger, 1988; Engle \& Granger, 1987). Given the positive association between quality and retention, they must move together permanently in the sense of the long runs. To investigate the temporary immediate term (or short run) relationship between quality and retention, we estimated a general form of FM-OLS error correction model $(\mathrm{ECM})$ whereby the error correction term (ECT) from the permanent (or long run) equation entered the ECM as one of the regressors (Hendry, 1995; Harris, 1995; Arize, Malindretos \& Grivoyannis, 2003; Arize, Malindretos \& Christoffersen, 2003). 
The general ECM results of the Phillips-Hansen FM-OLS are reported in Table 3 as the short run results. As you can see, Table 3 has some encouraging results. First, one period lagged changes in customer retention $(\triangle L C R(-1))$, is a significant predictor of current changes in customer retention. Second, current changes in quality $(\triangle L P Q)$ explains current changes in customer retention. Therefore, the empirical evidence suggests that customer perceived quality significantly explains current changes in customer retention. The managerial strategic management significance of this finding will be discussed in subsequent sections of this paper.

Finally, even though the diagnostic tests reported in Table 2 suggest model adequacy, we felt that confidence in the results would be enhanced if the model was re-estimated with a heteroscedasticity-consistent estimator. As would be expected, the probability values of the White's heteroscedasticity-consistent estimates are somewhat larger but are significant at the five per cent level, as shown in Table 3.

\section{Acknowledgement}

We are grateful to JA Duffy - former Editor - for the assistance she gave us in writing this paper, and to the three anonymous reviewers for their valuable comments that improved the quality of the paper.

Godwin Onyeaso is professor of strategic management and research methods at Concordia College-University System, Selma, Alabama, USA. His primary research interest is on the influence of intangible strategic assets (e.g., spiritual capital) on the performance of family businesses and large corporations. His contributions are published in several peer-reviewed joumals.

Chris Adalikwu is professor and chair, Division of Business, Concordia College-University System, Selma, Alabama, USA. As a Fulbright Scholar, he has extensive international experience in retailing and financial services management. He has researched and published in the workforce diversity management field in several peer-reviewed academic journals. 